\title{
Influence of School Board of Management Ability on Financial Planning Process in Public Primary Schools in Tharaka South Sub-County, Tharaka Nithi County, Kenya
}

\author{
Julia Kaimuri $^{1^{*}} \quad$ Dr. Denis Obote $(\mathrm{PhD})^{2} \quad$ Dr. Peter Kimanthi Mbaka $(\mathrm{PhD})^{3}$ \\ 1.Tharaka University College, P. O. Box, 20-60215, Marimanti \\ 2.Director postgraduate, Tharaka University College, P. O. Box, 20-60215, Marimanti \\ 3.Department of education, chukka university, P.O. Box 109, 60400, Chuka \\ * E-mail of the corresponding author: anna.smith@ncu.ca
}

\begin{abstract}
This study intended to investigate the influence of School Board of Management on financial planning in public primary schools in Tharaka South Sub-County, Tharaka-Nithi County, Kenya. Various studies have been done globally in support to financial planning in public primary schools however the current study was to cover Tharaka South Sub County. The study used Correlation Research Design. The target population was 2801 comprising of 2464 Board members 336 Head Teachers and one Sub County. A sample size of 338 was considered composing of 296 Board members, 41 Head Teachers and one Sub County Director of Education. The instruments used were; Board of Management Questionnaire, Head Teacher Questionnaire and Sub County of Education Interview Schedule. Piloting was done in the neighboring sub county of Tharaka North which had similar characteristics with the location of the study. The researcher purposively sampled 26 Board of management members and 26 Head Teachers has respondents who were thought to have useful information on financial management. Questionnaires' reliability was estimated at 0.852 for Board members and 0.826 for head teachers. The instruments were found reliable for data collection because the reliability was above 0.700 and hence accepted for the study. Data collected was analyzed using Statistical Package for Social Science (SPSS) version 25.0 for windows. The instrument's face and content validity were ascertained by the experts of Faculty of Education of Chuka University. The study established that Board of Management significantly predicts the financial planning process in public primary schools. The findings of the study found that financial planning was important undertaking that lead to school development and eventual academic achievement. The study established that trainings for Board members empowerment was on high demand in the area under study. It was recommended that the: BOM members should be involved in regular financial training and budgeting to overcome the ever increasing economic challenges and changing trends in financial management. Head-Teachers should involve BOM in the Planning to provide cost effective educational programs that meet children's needs. The school administrators should be accountable as far as expenditure within the budget is concerned and should show a high degree of transparency and accountability. Keywords:Financial Management, Board of Management, Financial Planning.
\end{abstract}

DOI: $10.7176 / \mathrm{JEP} / 12-35-01$

Publication date: December $31^{\text {st }} 2021$

\section{Introduction}

Education is most important tool of posturing development in any country. According to the World Bank (2012), management in education is often defined as the processes and practices designed to realize objectives at all levels of the education system. As countries seek to adopt their education systems to the needs of contemporary society, expectations for schools and school managers are changing. The school boards should initiate educational policies at the local level and have a responsibility towards excellence in education. The School Board Members are in charge putting in place school financial guidelines using government policies.

Allis (2004), presenting policy document on financial management in public institutions in New York United States, found that the School Boards of managements have influence and control over education decisions to effectively manage institution resource. The document established that the school Board members have mandated to be in control of all school's matters related to financial resources. A study in South Africa by Bush and Heystek (2003), on School governance, compared different school administration in the region and found that all school had the roles of school financial resource management where the processes of budgetary, planning and audit are to be empowered through capacity building.

In Kenya they are known as School Board of Management (BOM) according to Onderi\& Makori (2013). In Kenya they are legally mandated by the Ministry of Education under the Education Act 2013 to manage primary schools, Education act (2013).A study by Kimeu (2004), studying on the mandates of Board of Managements found that are they mainly involved in decision making activities. A study by Herlbert (2011) studying the influence of BOM members on the major management issues in school management found that Boards of School Managements have sole responsibility in processing, presenting, organization and running school affairs. It is on 
these frameworks when the needs and objective of the institution can be achieved. Caskey, J. (2006) on managing finances resources found that BOM process and rigorous discussion on issues of developments so that decision can be released and supported through trainings for empowerment. The Board of Managements (BOM) plays a crucial role in ensuring that the resources are well accounted for and well maintained for the overall achievement of quality education and achievement. What has brought about the need of the study is that most Board members in primary schools do not have knowledge on the financial resources management. Most School Board members have no financial resources management skills and yet in many instances they are charged with planning, budgeting and accounting for school projects which often fail to be completed due to poor supervision on the side of Board members Republic of Kenya (2011).

\section{Objective of the Study}

To examine the influence of School Board of Management ability on financial planning process in public primary schools in Tharaka South Sub-county, Tharaka Nithi County, Kenya.

\section{Research Hypothesis}

The study sought to test the following hypothesis at significance level of 0.05 . Ho1. There is no statistically significant influence of School BOM ability on planning process in public primary schools in Tharaka South Sub County, Tharaka Nithi County, Kenya.

\section{Literature Review}

\section{The Concept of Board of Management}

Chatiza (2011), in a study, Introduction to Education and Promoting Equality in Primary Schools in London found education is gate pass to development and it needs careful administration for success. The management of education through BOM was started way back as the study of Chatiza cited the work by Thenya (2017), studying on creation of School Boards in European countries like England, Wales and Scotland found that education was manageable by Local Education Authorities (LEA). In England and Wales, School Boards were public bodies between 1870 and 1902 which were created under the Elementary Education Act of 1870. However, they were created under the Education Act of 1902 which replaced them with Local Education. The findings also indicated that there are conflicting views on composition of the Boards, their roles and effectiveness as provided by law basing argument on the role they perform.

A study by Sergiovanni (2012), in London, indicated that School Boards of Managements in most parts of Europe served as an internal monitoring mechanism to protect the interests of government and shareholders. This study recommend in parts that schools to adopt school Board of Management as a strategy of governance in developing school towards better financial management. This new development in education management show school gaining more in terms of training for skills development in financial management. Board of Management refers to the body appointed by the Ministry of Education to run public Schools Kenya. Their core duty being to initiate reforms to all school-level stakeholders and create priorities to be associated with internal school improvement activities in a coherent way as they provide policy directions for schools, Stoll (2019).

Ford (2013), in America studying the impacts of School board governance on management of finance and human resources indicated that budgeting, planning and auditing play major role in resources allocation. The recommendations of the study delt more on skill acquisition and need for proper school governance. The study cited areas of budgeting, planning and auditing as target for skill development within the school Board of Management members to equip them for management task.

According to a study by Yau and Cheng (2011), In Hong Kong studying on Head teachers and Teachers' perceptions of school policy as a key element of school-based resource management found that School leadership plays a major role in education reform. The study found that there were several strategies for school improvement particularly on financial managerial issues which needs agreement that should be synchronized as one for better management by BOM members in schools. The study recommended interventions on budgeting, planning and auditing processes to be done through skill development for better governance.

A study by Iwu and Iwu (2013) in a case study in Ebonyi state in Nigeria trucking on Factors inhibiting effective School Boards of management of primary schools on resources allocation, found that BOM are vital in running schools in the region. The study spelt out roles of BOM as sole back bones of development in all school and so need for skill develop to ensure project success in schools. The study recommended training of BOM on budget formulating, planning school financial activities and auditing the school accounts and projects. Khama (2014) Studying nature and behavior of BOM roles in Namibia indicated that School Board members are sole development management units of schools. In many countries both state and independent schools, the future of the institution is within the control of the members of the individual school boards which are composed of appointed members working with the head teacher on all matters related to financial administration. The study pointed out that school managers, should take courses on financial management in budgeting, planning and 
auditing to gain skills in these areas.

According to Kenyan Basic Education Act 2013 BOMs are empowered to promote quality education for all pupils in accordance with the standards set under the Act empowered by the constitution. Also provides that the Cabinet Secretary appoints members of the board through the County Board Members. According to Chelimo (2007), studying School Board of Management duties and roles in governing the education institutions in Kenya, found that institutions are strengthen through budgeting, planning and auditing for resources acquired. The study found that school boards lack knowledge on school management and hence recommended training for empowerment. A study by Onderi, Makori (2013), shows that management is an important process of coordinating and integrating specialized priorities ina school covering all school objectives. A study by Chabari (2007), reveals that appointments of members of the Board of Management (BOM) is a replica of what is happening in other parts of the world. The Boards of Managements' (BOM) put in place to manage schools. Every Public School needs to have a functional BOM which are well- informed and trained. An effective board of Management has a clear understanding of its role and responsibilities. They are the policy implementers and work for the government to better education sector.

Financial Planning Process

Rabovsky (2011), on Accountability in higher education and Exploring impacts on state budgets and institutional spending in University of Oklahoma, USA attributed great Success in American education sector to financial management where planning was voted as major contributor. The Global Education Center proposed training for all School Management Boards to empower them with managerial planning skills. World Bank (2012), provided analyses that gave Support to School Boards in Scotland to adopt financial management and planning in Scottish school board of management. According to World Bank, Scotland institutions adopted the strategy and saved many project facing risks of grounding due to poor planning and management.

A study by Habibullah (2010), on School Management Committee (SMCs) and the Development of Education in Afghanistan, recorded trending changes towards better financial planning in the County. More educational institutions adopted the new move towards skills in education planning as a strategy. Wushe, Ndlovu and Shenje (2014), studying analysis of basic management and financial skills by school development committees (SDC) in selected Harare schools in South Africa found that Planning is a vital component in effective school financial administration and planning. The study in parts found that planning activities recommended the use of analyzed vote heads to calf repetition in budget allocations. The study also found that all aspects of procurement and disposal of unserviceable goods in the public sector which includes public schools should be put in line with planning to enhance accountability and transparency in expenditure, management and planning. The study recommended Public schools to adopt planning criterion in all schools in Harare. Maronga, Weda and Kengere (2013), in an International Journal of Scientific \& Technology Research investigating the influence of government financial management on Kenyan indicated that, school Boards are accounting officers on behave of the government at school level. Board of Management members are placed as policy makers of the institution. The study recommended need for training on financial management and planning to empower the board member for effective services delivery. The study found that Planning is a tool that governs what an institution should do to meet their obligations.

A study by Musee (2011), studying challenges facing BOMs in Kitui found that BOM members were greatly involved in approving budgets and setting financial priorities without proper planning criterion. The study recommended proper planning to achieve targeted priorities. From literature review provided, there is a great need for a study like this to be conducted in Tharaka South Sub County in Tharaka Nithi where public schools are at risk because they are managed without proper managerial skills in education planning as anticipated by the government. The studies done previously in other areas did not show the level of financial mismanagements through planning of activities in public schools. This prompted the need for further research to find out the remedy. These studies presented did not review the strategies adopted by public schools to ensure that funds are well managed through planning hence need for further research like this.

\section{Research Design}

The study adopted a Correlational Research Design. This research design enabled the researcher to explain the levels of predicted influence of BOM skills and ability on budgeting process, planning process in financial management.

\section{Target Population}

The target population of this study was 2801 composed of 2464 BOM members, 336 head Teachers and 1 subcounty director charged with the responsibility of running public primary schools in Tharaka South Sub-County. Each public school has most 13 board members inclusive of 336 Head Teacher and one Sub County of Education as an Ex- official member to all public schools under county jurisdiction. 


\section{Sampling Procedure and Sample Size}

Simple Random sampling was used to get 296 BOM out of 338. 41 Head Teachers out of 336 respondents and purposively picked the Sub County Director of Education of the total sample size. The sample is presented in table. Category of Participant's Sample Size and Sampling Methods

\begin{tabular}{lccl}
\hline Category & Target population & Sample size & Sampling method \\
\hline BOM & 2464 & 296 & Simple random \\
HTs & 336 & 41 & Simple random \\
SUBCDE & 1 & 1 & Purposive sampling \\
TOTAL & 2801 & 338 &
\end{tabular}

\section{Data Analysis}

The quantitative data was analyzed using descriptive statistics where the responses from the questionnaires was tallied, tabulated and analyzed using percentages, frequencies, mean and standard deviation using Statistical Package for Social Sciences (SPSS). Regression analysis was used to show the how the independent variable predict the dependent variable.

\section{Results and discussions}

The researcher used regression model to predict the influence of Board of Management Ability on financial planning process. The hypothesis for this study was that there is no statistically significant influence financial management on planning process in public primary schools in Tharaka South Sub County, Tharaka Nithi County, Kenya. The hypothesis was tested at $\propto=0.05$ significance level.

\section{Model Summary}

Model Summary on Planning Process

BOG Members $\quad \underline{\text { Head teachers }}$

\begin{tabular}{llllllllll}
\hline Model & $\mathrm{R}$ & R square & $\begin{array}{l}\text { Adjusted R } \\
\text { square }\end{array}$ & $\begin{array}{l}\text { S. Error } \\
\text { estimate }\end{array}$ & Model & $\mathrm{R}$ & $\begin{array}{l}\mathrm{R} \\
\text { square }\end{array}$ & $\begin{array}{l}\text { Adjusted R } \\
\text { square }\end{array}$ & $\begin{array}{l}\text { S. } \\
\text { estimate }\end{array}$ \\
1 & $.478 \mathrm{a}$ & .228 & .226 & .3657 & 1 & $.220 \mathrm{a}$ & .048 & 024 & .57103
\end{tabular}

a. Predictor: Board of Management Ability

From table value of R (0.478) for BOM and (0.220) for Head teachers in the model table indicated that there is high level of correlation between the two variables, BOM ability and financial planning process. The R square (coefficient analysis of determination) obtained was (0.228 and 0.048) for BOM members and head teachers respectively. This implies that according to BOM and Head Teachers the resulting $22.6 \%$ and $2.40 \%$ of Board of Management Ability predicts financial planning process.

Influence of BOM ability on Planning Process

\begin{tabular}{|c|c|c|c|c|c|}
\hline $\begin{array}{l}\text { Board of } \\
\text { Management } \\
\text { Response }\end{array}$ & & $\begin{array}{l}\text { Financial } \\
\text { planning }\end{array}$ & $\begin{array}{l}\text { Head teachers' } \\
\text { response }\end{array}$ & & Financial planning \\
\hline \multirow[t]{4}{*}{ BOM ability } & Pearson & $0.478 * *$ & BOM anility & Pearson & $0.220 * *$ \\
\hline & Correlation & 0.000 & & Correlation & 0.005 \\
\hline & Sig.(2tailed) & 296 & & Sig.(2tailed) & 41 \\
\hline & $\mathrm{n}$ & & & $\mathrm{n}$ & \\
\hline
\end{tabular}

**correlation is significant at the 0.01 level (2-tailed).

The analyzed data presented in table for BOM and head teachers revealed that Pearson correlation coefficient (r) is $0.478^{*}$ and $0.220^{* *}$ respectively. This is a strong relationship between independent variable of BOM ability and dependent variable financial planning process. The sig. (2tailed) or (p) value is 0.000 for BOM and 0.220 for head teachers, the sig (two tailed) for BOM respondents and head teachers respondents were less than 0.05 hence the null hypothesis rejected, therefore the null hypothesis was rejected at $95 \%$ level of confidence $(\propto=0.05)$. The drawn conclusion was that there was statistically significant influence of BOM ability on financial planning 
process.

A study by Habibullah (2010), on School Management Committee (SMCs) and the Development of Education in Afghanistan, recorded trending changes towards better financial planning in the County. More educational institutions adopted the new move towards skills in education planning as a strategy. This study recommended planning for all school activities for faster development. Maronga, Weda and Kengere (2013), in Kenyan indicated that, school Boards are accounting officers on behave of the government at school level. Board of Management members are placed as policy makers of the institution. The study recommended need for training on financial management and planning to empower the board member for effective services delivery. The current study also found that Planning is a tool that governs what an institution should do to meet their obligations.

\section{Conclusion}

The BOM Financial Management abilities influence Planning process in public primary schools in Tharaka South Sub County.

\section{Recommendation}

The government should take initiative to ensure that BOM members are equipped with necessary skills to perform the oversight function of school management. Principals should involve other BOM in the school system in planning to provide cost effective educational programs that meet children's needs. Those included should be those that are directly involved in the provision of education because they are in a better position to know the needs of their areas of jurisdiction. BOM skills.

\section{References}

Allis, R. P. M (2004), Financial Management: Ratio Analysis Zero to One Million. New York: McGraw-Hill.

Bush, T., \& Heystek, J. (2003). School Governance in the New South Africa. Compare: A Journal of Comparative and International Education, 33(2), 127-138.

Caskey, J. (2006). Can Personal Financial Management Education Promote Asset Accumulation by the Poor?. Networks Financial Institute Policy Brief, (2006-PB), 06.

Chabari, S. G (2007). Challenges Facing Primary School Management in Abegeta Divsion, Meru Central SubCounty Kenya. M.Ed Project Kenyatta University.

Chatiza,J.C. (2011). Introduction to Education Promoting Equality in Primary Schools. London:

Chelimo (2007). The Effectiveness of Board of Governors in Curriculum Implementation in Primary Schools in Keiyo Sub-County, for Education, Training and Research Nairobi: Government Printers

Ford, M. (2013). The Impact of School BOARD governance on Academic Achievement in Diverse States (Doctoral dissertation, The University of Wisconsin-Milwaukee).

Habibullah, M. S. (2010). Private Capital Flows, Stock Market and Economic Growth in Developed and Developing Countries: A Comparative Analysis. Japan and the World Economy, 22(2), 107-117.

Herlbert, I. (2011). The Financial Management Role of Principals in Section 21 Schools in South Durban, KwaZulu-Natal. Unpublished Master of Education project, University of South Africa, South Africa.

Iwu, C. G., \& Iwu, C. (2013). Factors Inhibiting Effective Management of Primary Schools in Nigeria: The Case of Ebonyi State. Journal of Social Sciences, 35(1), 51-60.

Kengere, D. O. (2013). An Investigation on the Influence of Government Financial Management on Kenyan Public Secondary Schools: A Case of Sameta Division. International Journal of Scientific \& Technology Research, 2(9), 96-101.

Kimeu, O. M. (2013). Individual Factors Influencing Competence of Board of Management Members in Human Resource Management of Public Secondary Schools in Kathonzweni District, Kenya (Doctoral dissertation, University of Nairobi).

Khama, N. R (2014). Views of Board Members on Management of Schools: A Case Study of Caprivi Educational Region of Namibia (Unpublished M.Ed thesis). University of Namibia, Namibia.

Kombo, D. K., \& Tromp, D. L. (2006). Proposal and Thesis Writing: An Introduction. Nairobi: Paulines Publications Africa, 5(1), 814-30.

Maronga, E., Weda, C.W., \& Kengere, D.O. (2013). An Investigation on the Influence of Government Financial Management on Kenyan public Secondary Schools: A Case of Sameta Division. International Journal of Scientific \& Technology Research, 2(9).

Musee, N. (2011). Nanowastes and the Environment: Potential New Waste Management Paradigm. Environment International, 37(1), 112-128.

Onderi, H., \& Makori, A. (2013). Differential Perceptions, Challenges, Conflicts and Tensions in the Role of Board of Governors (BOG) and Parent-Teacher Association (PTA) in Sub-Saharan Africa: A Case of Kenyan Secondary Schools. Educational Research, 3(1), 17-29.

Rabovsky, T. (2011).Accountability in Higher Education: Exploring Impacts on State Budgets and Institutional 
Spending. University of Oklahoma, USA.

Republic of Kenya (2011). Ministry of Education Strategic Plan (2006-2011). Nairobi: Government Printers.

Thenya, M. K. (2017). Individual Factors Influencing Effectiveness of Financial Management by Boards of Management At public Secondary Schools in Westlands Sub-county, Nairobi County, Kenya (Doctoral dissertation, University of Nairobi).

Sergiovanni, J. (2012). Managing Resources for School Improvement Creating a Cost-effective school. London.

World Bank. (2012). Governance, Management, and Accountability in PrimaryEducation in Sub-Saharan Africa. Washington, D.C.: World Bank

Yau, H. K., \& Cheng, A. L. F. (2011). Headteachers and Teachers'Perceptions of School Policy as a Key Element of School-Based Management in Hong Kong Primary Schools. Educational -Journal of Organizational Learning and Leadership, 9(1), 109-120. 